Hopkins A, ed. Headache. Problems in diagnosis and management. London: Saunders, 1988:241-67.

3 Headache Classification Committee of the International Headache Society. Classification and diagnostic criteria for headache disorders, cranial neuralgias and facial pain. 1st ed. Cephalalgia 1988;suppl 7:8.

4 Edmeads J. The cervical spine and headache. Neurology 1988;38:1874-8.

5 Bellavance A, Belzile G, Bergeron Y, Huot J, Meloche J, Morand M. Cervical spine and headaches. Neurolog 1989:39:1269.

6 Boquet J Bois. Non $F$, Payenneville G, Leclerc D, Monnier J-C Moore N. Boquet J, Boismare F, Payenneville G, Leclerc D, Monnier J-C, Moore Lateralization of headache: possible role of an upper cervical trigger point
Cephalalgia 1989;9:15-24.

7 Maimaris C, Barnes MR, Allen MJ. "Whiplash injuries" of the neck: a retrospective study. Injury 1988;19:393-6.

8 Martin PR, Nathan PR, Milech D, van Keppel M. The relationship between headaches and mood. Behav Res Ther 1988;26:353-6.

9 Arena JG, Blanchard EB, Andrasik F. The role of affect in the etiology of chronic headache. $\mathcal{f}$ Psychosom Res 1984;28:79-86.

10 Pearce JMS, Whiplash injury: a reappraisal. $f$ Neurol Neurosurg Psychiatry 1989;52:1329-31.

11 Hirsch SA, Hirsch PJ, Hiramoto H, Weiss A. Whiplash syndrome: fact or fiction? Orthop Clin North Am 1988;19:791-5.

12 Dvorak J, Valach L, Schmid S. Cervical spine injuries in Switzerland. Orhopade 1987;16:2-12.
13 Deans GT, Magalliard JN, Kerr M, Rutherford WH. Neck sprain-a majo cause of disability following car accidents. Injury 1987;18:10-2.

14 Norris SH, Watt I. The prognosis of the neck injuries resulting from rear-end vehicle collisions. $f$ Bone foint Surg [Br] 1983;65-B:608-11.

15 Zersson von D. Self-rating scales in the evaluation of psychiatric treatment. In Helgason T, ed. Methodology in the evaluation of psychiatric treatment. Cambridge: Cambridge University Press, 1983:183-204.

16 Watson D, Pennebaker JW. Health complaints, stress, and distress: exploring the central role of negative affectivity. Psychol Rev 1989;96:234-54.

17 Fahre ed. Gortingen: Dr C J Hogrefe, 1984

ed. Gơttingen: Dr C J Hogrefe, 1984. 1990:44-70.

19 Radanov BP, Dvorak J, Valach L. Cognitive deficits in patients after soft tissue injury of the cervical spine. Spine 1992;17:127-31.

20 Kelly R. Headache after cranial trauma. In: Hopkins A, ed. Headache. Problems in diagnosis and management. London: Saunders, 1988:217-40.

21 Lance WJ. Fifty years of migraine research. Aust N Z F Med 1988;18:311-7.

22 Martin PR, Marie GV, Nathan PR. Psychophysiological mechanisms of chronic headache: investigation using pain induction and pain reduction procedures. 7 Psychosom Res 1992;36:137-48.

(Accepted 13 fuly 1993)

\title{
The fish odour syndrome: biochemical, familial, and clinical aspects
}

\author{
R Ayesh, S C Mitchell, A Zhang, R L Smith
}

\section{Abstract}

Objectives-To study the biochemical, familial, and clinical features of the fish odour syndrome among subjects with suspected body malodour.

Design-Subjects who responded to a newspaper article were screened for the fish odour syndrome by interview and biochemical tests. Families of subjects with the syndrome were tested if possible.

Setting-St Mary's Hospital, London, and some interviews at subjects' homes.

Subjects -187 subjects (28 males) with suspected body malodour, of whom 156 (19 males) underwent biochemical tests. Five families of six of the subjects with the fish odour syndrome agreed to further tests.

Main outcome measures-Amounts of trimethylamine and trimethylamine $\mathbf{N}$-oxide in urine collected over 24 hours under normal dietary conditions and for eight hours after oral challenge with $600 \mathrm{mg}$ trimethylamine.

Results-The fish odour syndrome was diagnosed in 11 subjects: the percentage of total trimethylamine excreted in their urine samples that was oxidised to trimethylamine $\mathrm{N}$-oxide was $<55 \%$ under normal dietary conditions and $<25 \%$ after oral challenge with trimethylamine (in normal subjects $>80 \%$ of trimethylamine was $\mathrm{N}$-oxidised). Parents of six of the subjects with the syndrome were tested: all showed impaired $\mathbf{N}$-oxidation of excreted trimethylamine $(<80 \%)$ after oral challenge, indicating that they were heterozygous carriers of the allele for the syndrome. The syndrome was associated with various psychosocial reactions including clinical depression.

Conclusions-The fish odour syndrome can be inherited in an autosomal recessive fashion. It should be considered as a possible causative factor in patients complaining of body malodour.

\section{Introduction}

Although problems with body malodour have received little attention, they can cause much distress and may induce a variety of psychosocial reactions. We have been studying the incidence and biochemical nature of trimethylaminuria, known as the fish odour syndrome. People with this condition secrete the volatile and malodorous aliphatic tertiary amine trimethylamine in their breath, sweat, urine, and other bodily secretions. ${ }^{1}$ This amine smells strongly of rotting fish, and the human nose can detect it at very low concentrations $(<1 \mathrm{ppm}) .^{2}$

Trimethylamine is derived from the intestinal bacterial degradation of food components such as choline and carnitine. ${ }^{3}$ This is normally oxidised to odourless trimethylamine $\mathrm{N}$-oxide, which is excreted in the urine. ${ }^{4}$ The ability to $\mathrm{N}$-oxidise trimethylamine is distributed polymorphically in the population, and people with the fish odour syndrome appear to be homozygous for an allele which determines an impaired ability to carry out the $\mathrm{N}$-oxidation reaction..$^{5-7}$ The incidence of heterozygous carriers of the allele for impaired $\mathrm{N}$-oxidation in the population seems to be of the order of $1 \%,{ }^{5}$ which suggests the possible presence of several thousand people with the fish odour syndrome. Evidence to support the view that the condition is more common than hitherto thought came from the response to an article about the syndrome that was published in the Independent on 17 July 1991. We report some of the results of the clinical and biochemical studies of the people who responded to the newspaper article.

\section{Subjects and methods}

In response to an article in the Independent, which described some of the clinical features and psychosocial consequences of the fish odour syndrome, we received 187 spontaneous letters of inquiry from people who suspected that they or their children had body malodour. One of us (RA) interviewed 112 of the subjects (15 males) at St Mary's Hospital or at their homes, while 75 subjects (13 males) answered a questionnaire to give details of their age, sex, occupation, smoking and drinking habits, marital status, medical history, history of allergies, and nature of the malodour (self recognition of the malodour, its onset and duration, factors influencing its severity, family history of malodour, and history of previous medical advice and treatment). The subjects provided urine samples collected over 24 hours under normal dietary conditions and for eight hours after an oral challenge test with $600 \mathrm{mg}$ trimethylamine. The samples were analysed for free trimethylamine and trimethylamine $\mathrm{N}$-oxide: the samples collected after the oral challenge test allowed identification of heterozygous carriers of the allele for the fish odour syndrome. ${ }^{7}$

The subjects who were found to have the fish odour syndrome underwent routine haematological tests: full 
TABLE I-Urinary excretion of trimethylamine and trimethylamine $N$-oxide by 11 subjects with fish odour syndrome under normal dietary conditions (urine collected for 24 hours) and after oral challenge with $600 \mathrm{mg}$ trimethylamine (urine collected for eight hours)

\begin{tabular}{|c|c|c|c|c|c|c|}
\hline \multirow[b]{2}{*}{ Case No } & \multicolumn{3}{|c|}{ Normal diet } & \multicolumn{3}{|c|}{ Oral challenge } \\
\hline & $\begin{array}{c}\text { Trimethylamine } \\
(\mu \mathrm{mol})\end{array}$ & $\begin{array}{c}\text { Trimethylamine } \\
\text { N-oxide } \\
\text { ( } \mu \mathrm{mol})\end{array}$ & $\begin{array}{l}\text { \% Total amine } \\
\text { excreted as } \\
\text { N-oxide }\end{array}$ & $\begin{array}{l}\text { Trimethylamine } \\
(\mu \mathrm{mol})\end{array}$ & $\begin{array}{c}\text { Trimethylamine } \\
\text { N-oxide } \\
(\mu \mathrm{mol})\end{array}$ & $\begin{array}{l}\% \text { Total amine } \\
\text { excreted as } \\
\text { N-oxide }\end{array}$ \\
\hline 1 & 370 & 75 & 19 & 3765 & 340 & 9 \\
\hline $2^{\star}$ & 220 & 231 & 51 & 4220 & 1240 & 23 \\
\hline 3 & 510 & 95 & 18 & 1895 & 165 & 7 \\
\hline $4 \dagger$ & - & - & 16 & - & - & - \\
\hline 5 & 295 & 45 & 16 & 2875 & 140 & 5 \\
\hline 6 & 310 & 85 & 22 & 4500 & 580 & 11 \\
\hline 7 & 475 & 255 & 54 & 3145 & 1105 & 23 \\
\hline 8 & 315 & 136 & 37 & 3100 & 340 & 12 \\
\hline 9 & 620 & 57 & 11 & 4370 & 180 & 6 \\
\hline 10 & 360 & 135 & 41 & 2985 & 310 & 16 \\
\hline 11 & 430 & 140 & 25 & 3360 & 305 & 7 \\
\hline
\end{tabular}

*Urine collected for eight hours.

†Only spot urine sample available from 14 month old infant.

blood count, erythrocyte sedimentation rate, liver function tests, blood concentrations of urea and electrolytes, and serum concentrations of creatinine and thyroxine. The subjects' parents and siblings were also tested if possible: urine samples were collected over 24 hours under normal dietary conditions and for eight hours after the oral challenge test and were analysed.

Urine analyses-Urine samples were collected in bottles containing $10 \mathrm{ml}$ of $4 \mathrm{M} \mathrm{HCl}$ and were kept at $-20^{\circ} \mathrm{C}$ until analysis. The samples were analysed for trimethylamine and trimethylamine $\mathrm{N}$-oxide as described previously. ${ }^{8}$ Briefly, trimethylamine was released from the urine by the addition of alkali and was quantified by gas liquid chromatography. The amount of $\mathrm{N}$-oxide present was calculated from the increase in trimethylamine after reduction with aqueous titanous sulphate. Subjects were considered to be defective in the $\mathrm{N}$-oxidation of trimethylamine if $\leqslant 80 \%$ of the total urinary trimethylamine was excreted as the $\mathrm{N}$-oxide. Most people excrete $\geqslant 90 \%$ of their total trimethylamine as the $\mathrm{N}$-oxide. ${ }^{57}$

\section{Results}

Of the 187 white Britons we screened, 46 (13 males) smoked 10-20 cigarettes a day, 106 (19 males) drank two to eight measures of alcohol weekly, 98 ( 17 males) were single and six lived with partners, six females were asthmatic, one female had rheumatoid arthritis, two females had food sensitivity, 34 had been investigated or treated for depression, and nine females had been investigated for various gastrointestinal problems. Only 108 (14 males) of the subjects could categorise their particular body malodour while the remainder either did not perceive any odour or could describe it only in vague terms such as "unpleasant." After general clinical screening we could identify only 17 subjects (eight males) who might have the fish odour syndrome.

Of the 156 subjects (19 males) who provided urine samples for analysis, 139 complained of conditions other than fishy malodour. For these subjects the mean percentage of trimethylamine excreted as the $\mathrm{N}$-oxide was $88 \%$ (SD $10 \%$ (range $81-97 \%$ )) under normal dietary conditions and $89 \%(9 \%(82-95 \%))$ after challenge with $600 \mathrm{mg}$ trimethylamine (values similar to those established for a population of healthy white Britons ${ }^{57}$ ). Of the 17 subjects who complained of fishy body malodour, however, 11 showed a substantial increase in the urinary excretion of unoxidised trimethylamine and a decrease in the amount of trimethylamine $\mathrm{N}$-oxide (table I). The other six subjects showed no evidence of dysfunctional $\mathrm{N}$-oxidation of trimethylamine.

Table II shows details of the 11 subjects in whom the fish odour syndrome was clinically and biochemically diagnosed. None of them had any obvious physical or mental abnormality, and their general health was satisfactory. The results of their haematological tests were all within normal clinical limits (in cases 2 and 4 , however, these tests were not done). The subjects showed various psychosocial reactions: strong feelings of shame, embarrassment, low self esteem, social isolation, frustration, anxiety, depression, paranoia, suicidal personality, educational and career disadvantages, failure to maintain relationships with the opposite sex, and addiction to cigarettes, alcohol, and drugs.

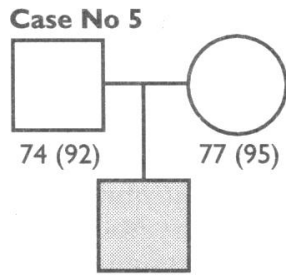

(16)

Case No 8 and 9

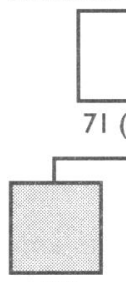

(37)
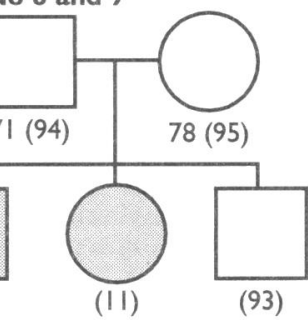

(93)

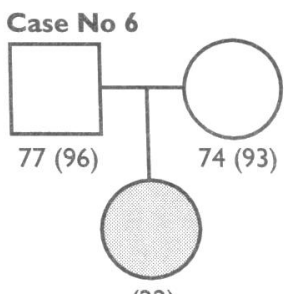

(22)

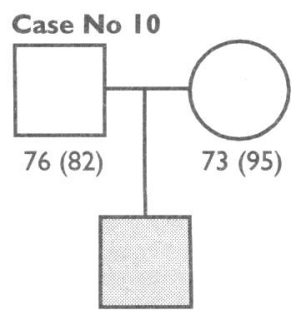

(4I)

Subjects with fish odour syndrome

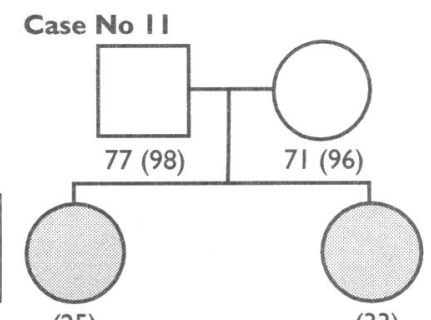

(25)

(33)

Studies of urinary excretion of trimethylamine by families of six subjects with fish odour syndrome. Values are percentages of total amine excreted as $\mathrm{N}$-oxide after oral challenge with $600 \mathrm{mg}$ trimethylamine (and under normal dietary conditions)

TABLE II-Clinical details of 11 subjects with fish odour syndrome

\begin{tabular}{|c|c|c|c|c|c|c|c|}
\hline Case No & $\begin{array}{l}\text { Age (years) } \\
\text { and sex }\end{array}$ & Cigarette smoking & $\begin{array}{l}\text { Other clinical } \\
\text { features }\end{array}$ & $\begin{array}{l}\text { Factors increasing } \\
\text { severity of malodour }\end{array}$ & $\begin{array}{l}\text { Age when } \\
\text { malodour first noticed }\end{array}$ & $\begin{array}{l}\text { Personal awareness } \\
\text { of malodour }\end{array}$ & $\begin{array}{c}\text { Family history of } \\
\text { malodour }\end{array}$ \\
\hline$\overline{1}$ & $23 \mathrm{~F}$ & - & - & Menstruation & 10 & - & - \\
\hline 2 & $14 \mathrm{~F}$ & - & - & - & Not known & - & - \\
\hline 3 & $27 M$ & Yes & Drug misuse & - & 13 & - & - \\
\hline 4 & 14 months $M$ & - & - & - & At birth & Not known & - \\
\hline 5 & $34 \mathrm{M}$ & - & - & - & 13 & Yes & - \\
\hline 6 & $37 \mathrm{~F}$ & Yes & - & Menstruation & Infancy & Yes & - \\
\hline 7 & $70 \mathrm{~F}$ & - & Rheumatoid arthritis & - & Not known & - & - \\
\hline $8^{\star}$ & $27 \mathrm{~F}$ & - & - & Menstruation & Infancy & - & Brother affected \\
\hline $9^{\star}$ & $22 \mathrm{M}$ & - & - & - & Infancy & Yes & Sister affected \\
\hline 10 & $32 \mathrm{M}$ & - & - & - & 30 & Yes & - \\
\hline 11 & $19 \mathrm{~F}$ & - & - & Oral contraception & 10 & - & Sister affected \\
\hline
\end{tabular}




\begin{tabular}{l} 
Clinical implications \\
\hline - Unpleasant body odour can be a source of \\
much distress for affected individuals \\
- The fish odour syndrome has been shown to \\
cause some cases of malodour \\
- We found that $7 \%$ of a group of subjects \\
complaining of unpleasant body odour had the \\
fish odour syndrome \\
- Family studies indicated that this condition \\
can be inherited as an autosomal recessive trait \\
- Increased awareness of the fish odour syn- \\
drome should help in the clinical management of \\
such distressed patients
\end{tabular}

We carried out urine analyses for the families of six of the subjects with the fish odour syndrome (figure). None of the subjects' parents had the syndrome, and they oxidised trimethylamine derived from their normal diet adequately. When they were orally challenged with $600 \mathrm{mg}$ trimethylamine, however, all the parents showed a deficiency in $\mathrm{N}$-oxidation, oxidising $<80 \%$ of the total trimethylamine excreted.

\section{Discussion}

Among 187 cases of suspected body malodour, we found 11 cases of clinically and biochemically defined fish odour syndrome. Probably about 30 cases of the syndrome have been described previously, but no detailed descriptions of the clinical consequences of the condition were given and in only two cases was an attempt made to test the ability of the parents of affected subjects to $\mathrm{N}$-oxidise trimethylamine. ${ }^{9}$ Our results suggest that the syndrome, which has received little attention and generally passes unrecognised, may not be as uncommon as previously thought. The syndrome appears to be inherited as a simple autosomal trait. All the subjects' parents whom we tested showed reduced metabolic capacity for $\mathrm{N}$-oxidation of trimethylamine when challenged with the amine. This response is characteristic of being a heterozygous carrier of the allele for the fish odour syndrome. ${ }^{7}$

Six of the 11 subjects we studied were unaware of their malodour problem while four could detect their own odour. Indeed, in one family the brother was aware of the problem while his sister claimed to be unaware of her malodour. We have previously observed this phenomenon, that some subjects are aware of their malodour while others are not, but its basis is not clear. We also found that the severity of the fishy malodour could vary. This could reflect variations in the dietary intake of precursors of trimethylamine, the status of the gastrointestinal microflora, or the functional activity of the flavin monooxygenase responsible for the $\mathrm{N}$-oxidation of trimethylamine.

This metabolic disorder can cause much personal distress, which may result in a variety of psychological reactions. Several of the subjects told us that their difficulties started at school in the form of ridicule, rejection, and remarks on their "dirtiness." Several fell behind with their education, and two subjects left school prematurely because of hostile reactions to their presence. Attempts to get medical help were sometimes unsuccessful: some subjects were diagnosed as obsessional when seen by psychiatrists while others who consulted dermatologists were advised to improve their personal hygiene. Social isolation and difficulties in initiating and sustaining personal relationships were common, sometimes leading to clinical depression and even attempts at suicide.

Sufferers and their families can derive considerable benefit from counselling: they are greatly relieved to learn that the condition is a recognised clinical disorder whose nature is to some extent understood and that they are not alone in suffering from it. Malodour can be reduced by managing the diet to reduce the ingestion of precursors of trimethylamine such as carnitine and particularly choline. Occasionally, a short course of neomycin and metronidazole to reduce the activity of the gut microflora can suppress production of trimethylamine. Subjects should be counselled that events such as menstruation, pyrexic states, and stress appear to exacerbate the problem.

The wider biological consequences of reduced activities or absence of flavin monooxygenases in people with the fish odour syndrome are unknown. It is possible that the metabolism and disposition of drugs that are metabolised by this enzyme system may be also changed in patients with the syndrome. Studies are now addressing the molecular basis of the disorder: there seem to be at least four isoenzymes of flavin monooxygenase in humans, and studies are under way to determine whether differences in the expression of one or more of these forms may underlie the fish odour syndrome. ${ }^{1011}$

We thank the Ministry of Agriculture, Fisheries and Food and the Kirkwood Trust for their support.

1 Humbert JR, Hammond KB, Hathaway WE, Marcoux JG, O'Brien D. Trimethylaminuria-the fish-odour syndrome. Lancet 1970;i:770-1.

2 willey GR. Trimethylamine-a pungent experience. Education in Chemistry 1985;22:178-81

3 Ayesh R, Smith RL. Genetic polymorphism of trimethylamine N-oxidation. Pharmacol Ther 1990;45:387-401.

4 Al-Waiz M, Mitchell SC, Idle JR, Smith RL. The metabolism of " $\mathrm{C}$-labelled trimethylamine and its N-oxide in man. Xenobiotica 1987;17:551-8.

5 Al-Waiz M, Ayesh R, Mitchell SC, Idle JR, Smith RL. A genetic polymorphism of the N-oxidation of trimethylamine in humans. Clin Pharmacol Ther 1987;42:588-94

6 Al-Waiz M, Ayesh R, Mitchell SC, Idle JR, Smith RL. Trimethylaminuria (fish-odour syndrome): study of an affected family. Clin Sci 1988;74:231-6.

7 Al-Waiz M, Ayesh R, Mitchell SC, Idle JR, Smith RL. Trimethylaminuria: Al-Waiz M, Ayesh R, Mitchell SC, Idle JR, Smith RL. Trimethylaminuria:
the detection of carriers using a trimethylamine load test. $\mathcal{f}$ Inherited Metab the detection of $\mathrm{Dis}$ 1989;12:80-5.

8 Zhang AQ, Mitchell SC, Ayesh R, Smith RL. Determination of trimethylamine and related aliphatic amines in human urine by head-space gas chromatography. I Chromatogr 1992;584:141-5.

9 Ayesh R, Smith RL. Genetic polymorphism of trimethylamine N-oxidation. In: Kalow W, ed. Pharmacogenetics of drug metabolism. New York: Pergamon Press, 1992:315-22.

10 Dolphin CT, Shephard EA, Povey S, Palmer CNA, Ziegler DM, Ayesh R, et al. Cloning, primary sequence and chromosomal mapping of a human flavincontaining monooxygenase FMO1. 7 Biol Chem 1991;266:12379-85.

11 Dolphin CT, Shephard EA, Povey S, Smith RL, Phillips IR. Cloning, primary sequence and chromosomal localization of human $\mathrm{FMO2}$, a new member of the flavin-containing monooxygenase family. Biochem f 1992;287:261-7.

(Accepted 24 fune 1993) 